\title{
Kendali Glikemik pada Pasien Diabetes Melitus Tipe 2 dengan dan tanpa Tuberkulosis Paru
}

\author{
Glycemic Control in Type 2 Diabetes Mellitus Patients with and without \\ Pulmonary Tuberculosis
}

\author{
Wahiduddin $^{1,2}$, Agung Pranoto ${ }^{3,4 *}$, Sudjarwo ${ }^{5}$ \\ ${ }^{1}$ Program Studi Kedokteran Jenjang Doktor Fakultas Kedokteran Universitas Airlangga \\ ${ }^{2}$ Departemen Epidemiologi Fakultas Kesehatan Masyarakat Universitas Hasanuddin \\ ${ }^{3}$ Departemen Ilmu Penyakit Dalam Fakultas Kedokteran Universitas Airlangga \\ ${ }^{4}$ RSUD Dr. Soetomo Surabaya, Jawa Timur \\ ${ }^{5}$ Departemen Kimia Farmasi Fakultas Farmasi Universitas Airlangga \\ (*agung-p@fk.unair.ac.id)
}

\begin{abstract}
ABSTRAK
Kendali glikemik merupakan hal yang penting bagi penyandang Diabetes Melitus (DM) karena berimplikasi terhadap upaya pengelolaan DM. Tuberkulosis (TB) paru merupakan salah satu komplikasi yang banyak pada pasien DM yang berhubungan dengan proses dan hasil pengobatan penyakit tersebut. Penelitian bertujuan mengetahui kendali glikemik berdasarkan parameter kadar Glukosa Darah Puasa (GDP), glukosa darah 2 jam post prandial (GD2JPP) dan HbA1c pada pasien diabetes melitus tipe 2 (DMT2) yang mengalami TB paru. Penelitian potong-lintang dilakukan pada 45 subyek DMT2 dengan TB paru dan 45 subyek DMT2 tanpa TB paru yang berobat jalan di dua rumah sakit di Surabaya. Hasil pemeriksaan GDP, GD2JPP, dan HbA1c yang dianalisis secara deskriptif, ditampilkan berupa nilai rerata dan Standar Deviasi (SD). Diperoleh rerata dan SD adalah GDP $(202,11$ $\pm 78,68 \mathrm{mg} / \mathrm{dl})$, GD2JPP $(283,20 \pm 107,20 \mathrm{mg} / \mathrm{dl})$, dan HbA1c $(11,20 \pm 2,61 \%)$ pada subyek DMT2 dengan TB paru sedangkan pada subyek DMT2 tanpa TB paru diperoleh GDP $(175,29 \pm 61,38 \mathrm{mg} / \mathrm{dl})$, GD2JPP $(208,22 \pm$ $75,60 \mathrm{mg} / \mathrm{dl})$, dan HbA1c $(9,34 \pm 2,22 \%)$. Nilai rerata GDP, GD2JPP dan HbA1c pasien DMT2 dengan TB paru lebih tinggi daripada DMT2 tanpa TB paru. Hal ini menunjukkan kriteria pengendalian DM yang belum mencapai sasaran sehingga perlu dilakukan upaya pemantauan kendali glikemik yang lebih baik.
\end{abstract}

Kata kunci : Diabetes melitus tipe 2, tuberkulosis paru , GDP, GD2JPP, HbA1c

\section{ABSTRACT}

Glycemic control is important for people with diabetes mellitus (DM) because it has implications for efforts to manage DM. Pulmonary tuberculosis (PTB) is one of the many complications in DM patients associated with the process and results of treatment of the disease. The study aimed to determine glycemic control based on parameters of fasting blood glucose level (FBG), 2 hours post prandial blood glucose (2hPBG) and HbAlc in patients with type 2 diabetes mellitus (T2DM) who had pulmonary TB. A cross-sectional study was conducted on 45 $T 2 D M$ subjects with PTB and 45 T2DM subjects without PTB who were outpatient in two hospitals in Surabaya. The results of the examination of $F B G, 2 h P B G$, and HbAlc were analyzed descriptively, displayed in the form of mean values and standard deviations (SD). The mean and SD were FBG (202.11 $\pm 78.68 \mathrm{mg} / \mathrm{dl}), 2 \mathrm{hPBG}(283.20$ $\pm 107.20 \mathrm{mg} / \mathrm{dl})$, and $\mathrm{HbAlc}(11.20 \pm 2.61 \%)$ in T2DM subjects with pulmonary TB while subjects without pulmonary TB were obtained $F B G(175.29 \pm 61.38 \mathrm{mg} / \mathrm{dl}), 2 \mathrm{hPBG}(208.22 \pm 75.60 \mathrm{mg} / \mathrm{dl})$, and $\mathrm{HbAlc}(9.34 \pm 2.22 \%)$. The mean of FBG, $2 h P B G$ and HbAlc of T2DM patients with pulmonary TB were higher than T2DM without pulmonary TB. This shows that the control criteria for DM that have not yet reached the target need to be done in an effort to better monitor glycemic control.

Keywords : Type 2 diabetes mellitus, pulmonary tuberculosis, FBG, 2hPBG, HbAlc 


\section{PENDAHULUAN}

Pemantauan status metabolik penyandang Diabetes Melitus (DM) merupakan hal yang penting dan sebagai bagian dari pengelolaan DM. Hasil pemantauan digunakan untuk menilai manfaat pengobatan dan sebagai pegangan penyesuaian diet, latihan jasmani dan obat-obatan untuk mencapai kadar glukosa darah senormal mungkin terhindar dari keadaan hiperglikemia ataupun hipoglikemia. Untuk mengetahui status metabolik penyandang DM dapat dinilai dari beberapa parameter diantaranya kadar glukosa darah, kadar hemoglobin glikat, kadar lipid darah, perubahan berat badan dan juga perasaan sehat secara subyektif. Definisi DM yang terkendali adalah apabila kadar glukosa darah, kadar lipid dan HbAlc mencapai kadar yang diharapkan serta status gizi maupun tekanan darah sesuai target yang ditentukan. ${ }^{1,2}$

International Diabetes Federation (IDF) pada tahun 2013 menempatkan Indonesia pada urutan ke tujuh dunia dengan penderita diabetes sebanyak 8,5 juta kasus pada penduduk usia 20-79 tahun serta hasil Riset Kesehatan Dasar (Riskesdas) 2013 menunjukkan prevalensi diabetes sebesar $6,9 \%$ pada penduduk usia 15 tahun ke atas. ${ }^{3,4}$ Sementara itu data Global Tuberculosis Report tahun 2015 menunjukkan Indonesia berada pada urutan ke dua dunia dengan jumlah kasus TB paru sebanyak 193.321 kasus baru serta 6.449 kasus kambuh. ${ }^{5,6}$

Indonesia merupakan salah satu negara berkembang dengan beban ganda DM dan TB yang tinggi selain India, Cina, Brazil, Rusia, Pakistan dan Bangladesh. ${ }^{7}$ Melalui berbagai penelitian di tingkat populasi menunjukkan prevalensi TB pada pasien DM ditemukan sekitar 1,7\% sampai $36 \%{ }^{8}$ Kejadian tuberkulosis paru pada pasien diabetes melitus tipe 2 (DMT2) di dua rumah sakit Indonesia masing-masing menemukan insidensi sebesar $3,88 \%$ pada pasien DMT2 yang rawat inap penyakit dalam selama tahun 2011 dan prevalensi sebesar $28,2 \%$ pada pasien DMT2 yang masih berobat jalan selama bulan Oktober-November 2013. ${ }^{9,10}$

DM menjadi salah satu faktor yang memengaruhi kejadian tuberkulosis (TB), pada kondisi DM terjadi penurunan respons imun penderita yang selanjutnya dapat mempermudah terjadinya infeksi oleh Mycobacterium tuberculosis yang berkembang menjadi penyakit TB. ${ }^{5}$ Sistem kekebalan terhadap TB menjadi terganggu pada pasien DM sehingga beban awal jumlah Mycobacterium tuberculosis lebih tinggi, waktu konversi sputum lebih lama. Dampak lain dari komorbiditas DMTB antara lain memengaruhi gejala klinis dan respons lambat pengobatan $\mathrm{TB}$, reaktivasi $\mathrm{TB}$ meningkat, TB-MDR memungkinkan meningkat, menginduksi terjadinya intoleransi glukosa serta memperburuk kontrol glikemik. ${ }^{11}$ Hal tersebut menjadikan kondisi DM sebagai salah satu faktor risiko terpenting yang berpengaruh terhadap perburukan TB paru. ${ }^{12}$

Pengendalian TB diperkirakan akan mengalami kendala seiring dengan peningkatan prevalensi penderita DM, untuk itu pada kondisi komorbiditas DM-TB prinsip pengobatan yang baik terhadap DM dan TB paru secara bersamaan perlu diperhatikan. Pengontrolan gula darah yang baik menjadi utama dan terpenting yang perlu diperhatikan agar keberhasilan pengobatan TB paru pada pasien DM dapat tercapai. ${ }^{12}$ Penelitian ini bertujuan untuk mengetahui pengendalian DM dengan parameter hasil pemeriksaan kadar glukosa darah puasa (GDP), glukosa darah 2 jam post prandial (GD2JPP), dan HbA1c pada pasien DMT2 dengan dan tanpa TB paru.

\section{BAHAN DAN METODE}

Penelitian ini menggunakan metode cross sectional. Pengumpulan data subyek penelitian dilakukan di Poliklinik Endokrin, Klinik Penyakit Dalam, dan Klinik Paru di dua rumah sakit pemerintah di Surabaya dari bulan Oktober 2017 sampai Januari 2018. Pengambilan subyek dilakukan secara consecutive sampling sebanyak 45 pasien DMT2 dengan TB paru dan 45 pasien DMT2 tanpa TB paru. Kriteria inklusi yang dipakai yaitu pasien DMT2 berusia 18-65 tahun, fungsi faal hati dan faal ginjal dalam batas normal, tidak merokok dan tidak mengonsumsi minuman alkohol. Kriteria eksklusinya yakni pasien DMT2 dengan kelainan penyakit keganasan paru, penyakit jantung atau pembuluh darah yang berat, kelainan jiwa berat, penyakit gagal ginjal, penyakit atopi berat, HIV dan AIDS, leukemia, limfoma maligna yang diperoleh dari hasil rekam medis rumah sakit. Penelitian ini telah mendapatkan keterangan kelaikan etik No. 533/Panke.KKE/IX/2017 dari 
komite etik RSUD Dr. Soetomo Surabaya pada tanggal 10 September 2017.

Hasil pemeriksaan GDP, GD2JPP, dan $\mathrm{HbA1c}$ diperoleh dari hasil laboratorium patologi klinik rumah sakit melalui pemeriksaan kimia klinik yang tercatat pada rekam medis pasien. Data dianalisis secara deskriptif dan ditampilkan berupa nilai rerata dan standard deviasi (SD) dan disajikan dalam tabel dan grafik.

\section{HASIL}

Subyek penelitian pada DMT2 dengan TB paru berusia antara 28 sampai 65 tahun, jenis kelamin perempuan sebanyak 24 orang $(53,33 \%)$ sedangkan laki-laki sebanyak 21 orang $(46,67 \%)$. Perbandingan perempuan dengan laki-laki adalah 1,14 : 1. Hasil Indeks Massa Tubuh (IMT) berkisar dari $14,06 \mathrm{~kg} / \mathrm{m}^{2}$ sampai $30,45 \mathrm{~kg} / \mathrm{m}^{2}$ dengan lama sakit DMT2 antara satu sampai 20 tahun. Hasil pengukuran tekanan darah berdasarkan nilai tekanan darah sistolik yakni $83 \mathrm{mmHg}$ sampai 169 $\mathrm{mmHg}$ sedangkan tekanan darah diastolik yakni $46 \mathrm{mmHg}$ sampai $97 \mathrm{mmHg}$. Hasil pengukuran tekanan darah baik sistolik maupun diastolik relatif masih normal yakni rerata $129,56 \mathrm{mmHg}$ dan $74,78 \mathrm{mmHg}$. Fungsi ginjal dalam batas normal yakni nilai BUN dari $5 \mathrm{mg} / \mathrm{dl}$ sampai $32 \mathrm{mg} /$ dl sedangkan nilai serum kreatinin dari $0,5 \mathrm{mg} / \mathrm{dl}$ sampai $1,3 \mathrm{mg} / \mathrm{dl}$. Fungsi hati juga dalam batas normal yakni SGPT dari $10 \mathrm{u} / 1$ sampai $55 \mathrm{u} / 1 \mathrm{se}-$ dangkan SGOT dari $9 \mathrm{u} / 1$ sampai $37 \mathrm{u} / 1$. Sebagian besar karakteristik subyek dengan DMT2 tanpa TB paru mempunyai rerata lebih tinggi dibandingkan dengan DMT2 dengan TB paru, dapat dilihat pada Tabel 1.

Berbagai bukti menyatakan kendali glikemik berhubungan dengan menurunnya komplikasi diabetes. Berbagai studi menyatakan dengan menjaga kadar glukosa plasma rata-rata tetap rendah menunjukkan insidensi komplikasi mikrovaskuler seperti retinopati diabetik, nefropati, dan neuropati yang lebih rendah. Target glikemik berdasarkan parameter GDP, GDPP, dan HbA1c menurut ADA 2015 yakni masing-masing $80-130 \mathrm{mg} / \mathrm{dl},<180$ $\mathrm{mg} / \mathrm{dl}$ dan $<7 \%$ (individual). ${ }^{1,2}$

Pada semua subyek penelitian, kadar GDP berada pada kisaran $82 \mathrm{mg} / \mathrm{dl}$ sampai $467 \mathrm{mg} /$ dl. Kadar GD2JPP pada kisaran 104 mg/dl sam-

Tabel 1. Karakteristik Demografi dan Pemeriksaan Klinis Pasien Diabetes Melitus Tipe 2 dengan dan tanpa Tuberkulosis Paru

\begin{tabular}{lcc}
\hline \multicolumn{1}{c}{ Karakteristik } & $\begin{array}{c}\text { DMT2 dengan TB Paru } \\
(\text { rerata } \pm \text { SD) }\end{array}$ & $\begin{array}{c}\text { DMT2 tanpa TB Paru } \\
\text { (rerata } \pm \text { SD) }\end{array}$ \\
\hline Usia, tahun & $51,91 \pm 7,93$ & $55,78 \pm 7,36$ \\
Jenis kelamin, laki-laki/perempuan & $21 / 24$ & $5 / 40$ \\
Indeks Massa Tubuh, $\mathrm{kg} / \mathrm{m}^{2}$ & $22,39 \pm 3,71$ & $26,13 \pm 3,99$ \\
Lama diabetes, tahun & $5,53 \pm 4,96$ & $9,60 \pm 6,95$ \\
Tekanan darah sistolik, mmHg & $129,56 \pm 18,39$ & $139,80 \pm 18,94$ \\
Tekanan darah diastolik, mmHg & $74,78 \pm 11,44$ & $78,64 \pm 13,43$ \\
BUN, mg/dl & $14,13 \pm 4,99$ & $15,07 \pm 3,61$ \\
Kreatinin, mg/dl & $0,88 \pm 0,22$ & $0,86 \pm 0,23$ \\
SGPT, u/l & $20,71 \pm 10,82$ & $22,93 \pm 9,19$ \\
SGOT, u/l & $18,33 \pm 6,44$ & $18,26 \pm 4,95$ \\
\hline
\end{tabular}

Tabel 2. Hasil Pemeriksaan GDP, GD2JPP, dan HbA1c Pasien Diabetes Melitus Tipe 2 dengan dan tanpa Tuberkulosis Paru

\begin{tabular}{lcc}
\hline \multicolumn{1}{c}{ Hasil Pemeriksaan Glukosa } & $\begin{array}{c}\text { DMT2 dengan TB Paru } \\
(\text { rerata } \pm \text { SD) }\end{array}$ & $\begin{array}{c}\text { DMT2 tanpa TB Paru } \\
\text { (rerata } \pm \text { SD) }\end{array}$ \\
\hline GDP, $\mathrm{mg} / \mathrm{dl}$ & $202,11 \pm 78,68$ & $175,29 \pm 61,38$ \\
GD2JPP, $\mathrm{mg} / \mathrm{dl}$ & $283,20 \pm 107,20$ & $208,22 \pm 75,60$ \\
HbA1c, $\%$ & $11,20 \pm 2,61$ & $9,34 \pm 2,22$ \\
\hline
\end{tabular}


Tabel 3. Distribusi Sasaran Pengendalian DM Menurut Parameter Indeks Massa Tubuh, Tekanan darah, GDP, GD2JPP, dan HbA1c Pasien Diabetes Melitus Tipe 2 dengan dan tanpa Tuberkulosis Paru

\begin{tabular}{|c|c|c|}
\hline $\begin{array}{c}\text { Parameter Sasaran } \\
\text { Pengendalian DM }\end{array}$ & $\begin{array}{c}\text { DMT2 dengan TB Paru } \\
\text { n(\%) }\end{array}$ & $\begin{array}{c}\text { DMT2 tanpa TB Paru } \\
\text { n(\%) }\end{array}$ \\
\hline \multicolumn{3}{|l|}{ Indeks Massa Tubuh (IMT) } \\
\hline$<18,5 \mathrm{~kg} / \mathrm{m}^{2}$ & $6(13,3)$ & $2(4,4)$ \\
\hline $18,5-22.99 \mathrm{~kg} / \mathrm{m}^{2}$ & $21(46,7)$ & $6(13,3)$ \\
\hline$>23 \mathrm{~kg} / \mathrm{m}^{2}$ & $18(40,0)$ & $37(82,2)$ \\
\hline \multicolumn{3}{|l|}{ Tekanan Darah Sistolik } \\
\hline$<140 \mathrm{mmHg}$ & $33(73,3)$ & $26(57,8)$ \\
\hline$\geq 140 \mathrm{mmHg}$ & $12(26,7)$ & $19(42,2)$ \\
\hline \multicolumn{3}{|l|}{ Tekanan Darah Diastolik } \\
\hline$<90 \mathrm{mmHg}$ & $39(86,7)$ & $35(77,8)$ \\
\hline$\geq 90 \mathrm{mmHg}$ & $6(13,3)$ & $10(22,2)$ \\
\hline \multicolumn{3}{|l|}{ GDP, $\mathrm{mg} / \mathrm{dl}$} \\
\hline $80-130 \mathrm{mg} / \mathrm{dl}$ & $6(13,3)$ & $9(20,0)$ \\
\hline$>130 \mathrm{mg} \mathrm{dl}$ & $39(86,7)$ & $36(80,0)$ \\
\hline \multicolumn{3}{|l|}{ GD2JPP, mg/dl } \\
\hline$<180 \mathrm{mg} / \mathrm{dl}$ & $1(2,2)$ & $2(4,4)$ \\
\hline$\geq 180 \mathrm{mg} / \mathrm{dl}$ & $44(97,8)$ & $43(95,6)$ \\
\hline \multicolumn{3}{|l|}{ HbA1c, \% } \\
\hline$<7 \%$ & $3(6,7)$ & $4(8,9)$ \\
\hline$>7 \%$ & $42(93,3)$ & $41(91,1)$ \\
\hline
\end{tabular}

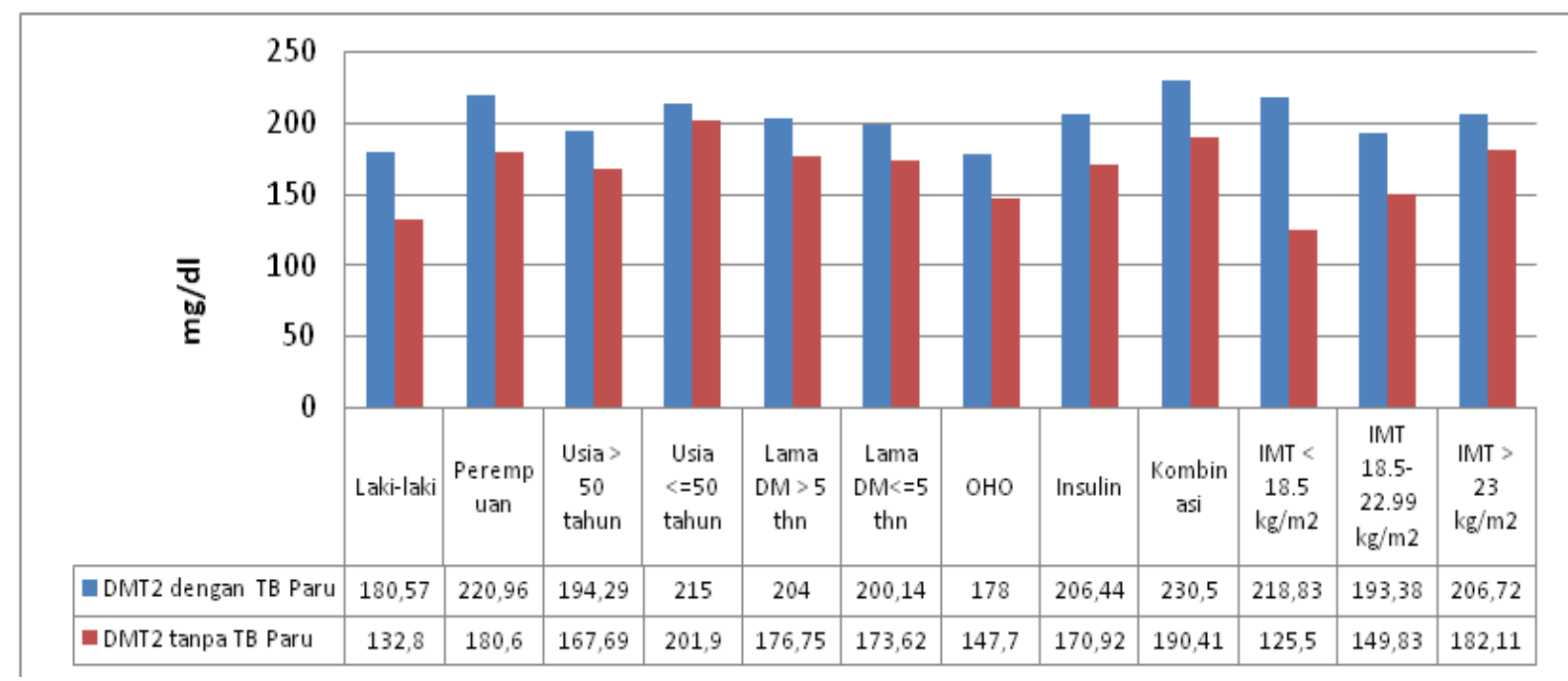

Grafik 1. Hasil Perbandingan GDP menurut Jenis Kelamin, Kelompok Usia, Lama sakit, Pengobatan,dan IMT pada Pasien DMT2 dengan dan tanpa TB Paru

pai $546 \mathrm{mg} / \mathrm{dl}$ dan nilai $\mathrm{HbA} 1 \mathrm{c}$ berada pada kisaran $6,5 \%$ sampai $14,6 \%$. Tabel 2 menunjukkan perbandingan rerata GDP, GDPP dan HbA1c pada pasien DMT2 dengan TB paru lebih tinggi dibandingkan dengan DMT2 tanpa TB paru. Kadar HbA1c juga berkorelasi dengan kadar gula darah acak, gula darah post prandial dan GDP, tetapi de- mikian GD2JPP lebih menunjukkan korelasi yang lebih kuat. Pada penelitian ini didapatkan rerata GD2JPP masing-masing 283,20 pada DMT2 dengan TB paru mg/dl dan 211,49 mg/dl pada DMT2 tanpa TB paru yang artinya masih banyak subyek dengan kendali glukosa darah yang buruk karena belum memenuhi sasaran pengendalian target glu- 


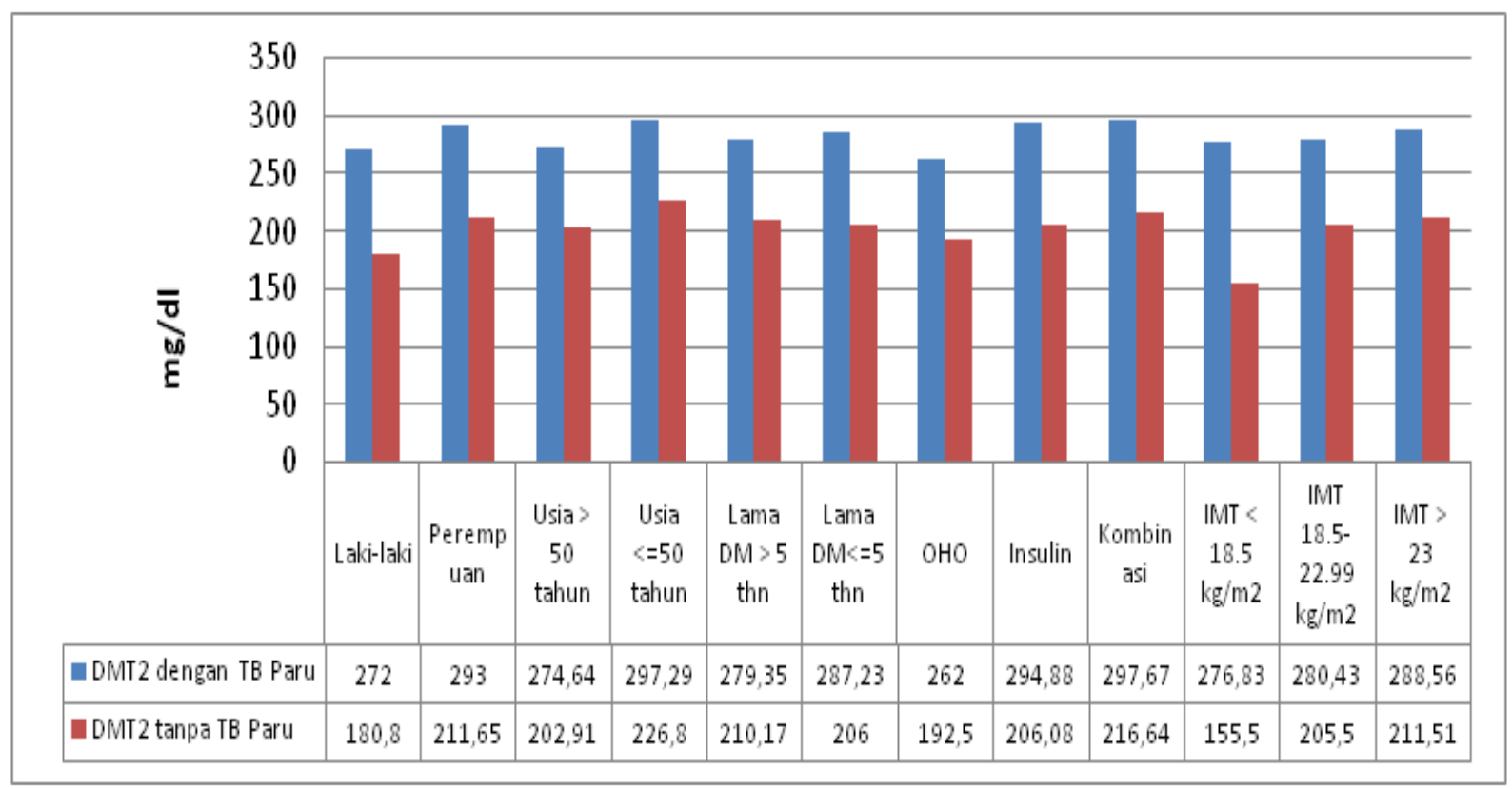

Grafik 2. Hasil Perbandingan GD2JPP menurut Jenis Kelamin, Kelompok Usia, Lama sakit, Pengobatan, dan IMT pada Pasien DMT2 dengan dan tanpa TB Paru

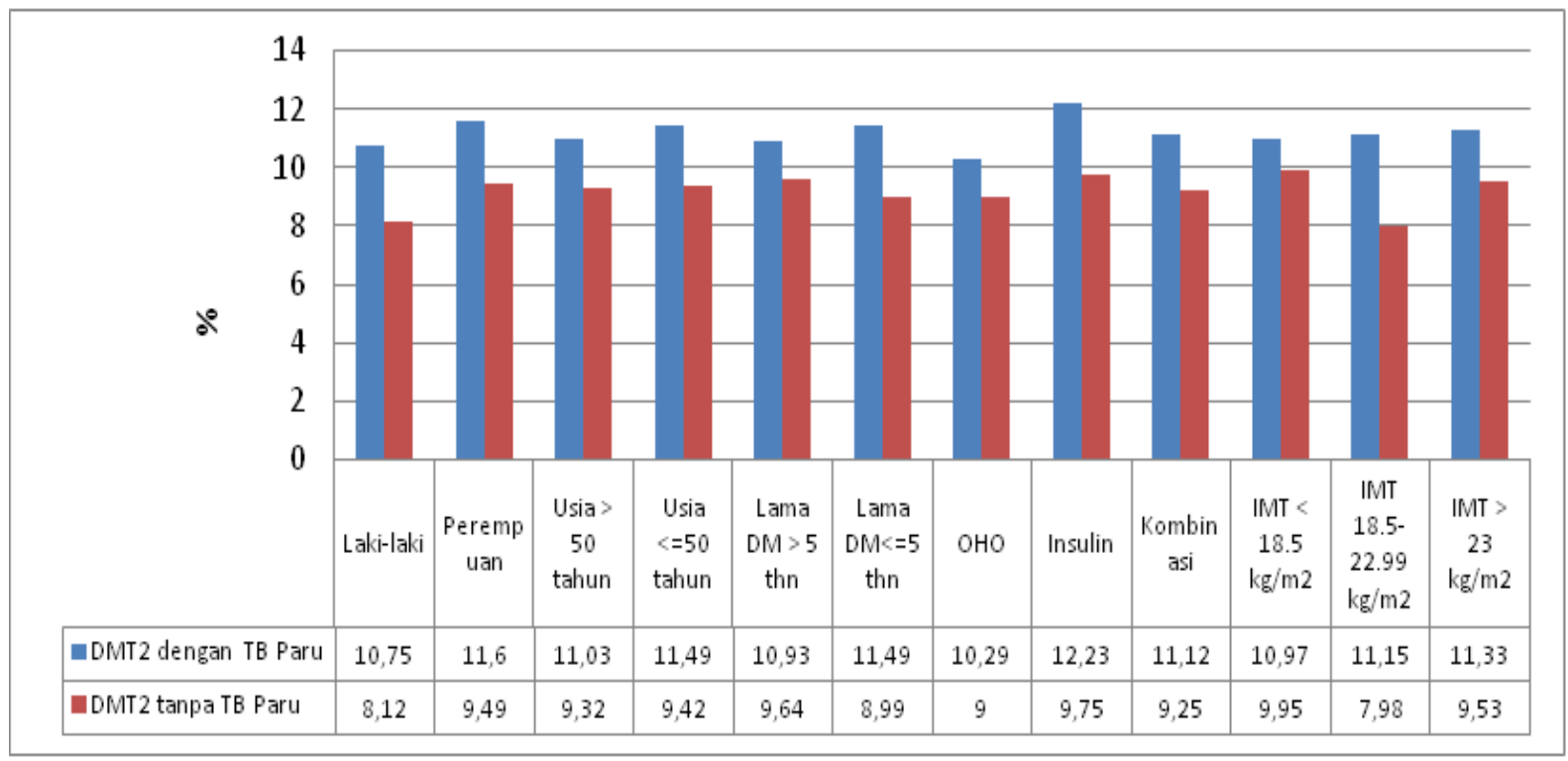

Grafik 3. Hasil Perbandingan HbA1c menurut Jenis Kelamin, Kelompok Usia, Lama sakit, Pengobatan, dan IMT pada Pasien DMT2 dengan dan tanpa TB Paru

kosa darah post prandial yakni $<180 \mathrm{mg} / \mathrm{dl}$ sesuai dengan PERKENI 2015. ${ }^{2}$

Tabel 3 menunjukkan hasil penelitian yang menggunakan beberapa parameter sasaran pengendalian DM yaitu IMT, tekanan darah, GDP, GD2JPP, dan HbA1c. Subyek DMT2 dengan TB paru mempunyai proporsi $46,67 \%$ berdasar- kan parameter IMT yakni $18,5-<23 \mathrm{~kg} / \mathrm{m}^{2}$ lebih tinggi dibandingkan DMT2 tanpa TB paru yakni hanya $11,63 \%$. Sedangkan parameter pemeriksaan tekanan darah baik tekanan darah sistolik $<140 \mathrm{mmHg}$ maupun tekanan darah diastolik $<90$ $\mathrm{mmHg}$ secara umum memenuhi sasaran pengendalian pada kedua kelompok. Berdasarkan para- 
meter GDP, GD2JPP, dan HbA1c hasil penelitian ini menunjukkan sasaran pengedalian DM belum tercapai bahkan dalam kategori pengendalian glikemik yang buruk.

Grafik 1 menunjukkan hasil perbedaan rerata GDP pada subyek DMT2 dengan TB paru ditemukan lebih tinggi dibandingkan DMT2 tanpa TB paru berdasarkan jenis kelamin perempuan, kelompok umur $\leq 50$ tahun, lama sakit DMT2 $>5$ tahun, pengobatan dengan kombinasi $\mathrm{OHO}$ dan insulin, serta IMT $<18,5 \mathrm{~kg} / \mathrm{m}^{2}$. Berdasarkan Grafik 2 diperoleh hasil perbedaan rerata GD2JPP pada subyek DMT2 dengan TB paru juga ditemukan lebih tinggi dibandingkan DMT2 tanpa TB paru berdasarkan jenis kelamin perempuan, kelompok umur $\leq 50$ tahun, lama sakit DMT2 $\leq 5$ tahun, pengobatan dengan kombinasi OHO dan insulin, serta IMT $>23 \mathrm{~kg} / \mathrm{m}^{2}$.

Perbedaan rerata $\mathrm{HbA1c}$ pada kelompok DMT2 dengan TB paru ditemukan lebih tinggi dibandingkan DMT2 tanpa TB paru, dilihat pada Grafik 3, yang menunjukkan rerata $\mathrm{HbA} 1 \mathrm{c}$ perempuan mencapai $11,6 \%$, kelompok usia $\leq 50$ tahun dan lama sakit DMT2 $\leq 5$ tahun masing-masing mencapai $11.49 \%$, penggunaan insulin serta IMT $>23 \mathrm{~kg} / \mathrm{m}^{2}$ mempunyai $\mathrm{HbAlc}$ yang tertinggi.

\section{PEMBAHASAN}

Terkendalinya kadar glukosa darah, tidak hanya tergantung pada hilangnya gejala diabetes melitus saja, tetapi harus dengan pemeriksaan kadar glukosa darah. Pemantauan kadar glukosa darah dapat dilakukan diantaranya melalui pemeriksaan di laboratorium saat penyandang DM berkonsultasi ke klinik atau rumah sakit. ${ }^{1}$

Pada penelitian ini pengendalian DM pada penyandang DMT2 dengan dan tanpa TB paru menggunakan kriteria berdasarkan parameter hasil pemeriksaan GDP, GD2JPP, dan HbA1c. Data IMT, hasil pengukuran tekanan darah sistolik dan diastolik juga menjadi parameter lain selain hasil pemeriksaan kadar lipid dalam menentukan kriteria pengendalian DM berdasarkan Konsensus PERKENI 2015. ${ }^{2}$

Pemeriksaan GDP bertujuan untuk mengetahui respons insulin dalam menjaga keseimbangan gula darah, sebelum pemeriksaan dilakukan pasien diminta berpuasa selama 8 jam penuh tanpa makan. Sedangkan pemeriksaan GD2JPP dilaku- kan untuk memeriksa kadar gula darah 2 jam setelah makan. Dua jam setelahnya akan dilakukan pemeriksaan gula darah yang dipakai untuk menilai seberapa besar fungsi pankreas ataupun insulin yang dikeluarkan untuk menetralisir gula darah.

HbAlc merupakan komponen minor dari hemoglobin yang berikatan dengan glukosa, digunakan untuk memantau glukosa darah pada pasien diabetes. Pemeriksaan HbAlc merupakan pemeriksaan yang penting untuk melihat seberapa baik pengobatan terhadap diabetes. Hal ini berarti pemeriksaan $\mathrm{HbA} 1 \mathrm{c}$ ini akan menggambarkan rerata gula darah selama 2 sampai 3 bulan terakhir yang digunakan bersama dengan pemeriksaan gula darah biasa untuk membuat penyesuaian dalam pengendalian diabetes melitus. Nilai HbAlc adalah indikator jangka panjang terhadap kontrol glukosa darah yang juga digunakan untuk memonitor efek dari diet, olahraga, dan terapi obat terhadap keadaan gula darah pasien.

Hasil penelitian menunjukkan rerata usia pasien DMT2 dengan TB yakni $>51$ tahun. Subyek perempuan lebih banyak dibandingkan lakilaki yakni 53,33\%, rerata IMT, yaitu $22,39 \mathrm{~kg} /$ $\mathrm{m}^{2}$ yang berarti masih normal. Lama terdiagnosis diabetes rerata lebih 5 tahun yang berarti relatif masih baru serta usia saat mengalami diabetes sebagian besar di bawah 50 tahun.

Berbagai penelitian terhadap pasien DMT2 dengan TB paru telah dilakukan diantaranya di Shandong Cina pada pasien DMT2 berusia 25 tahun ke atas mendapatkan rerata usia pasien DMT2 dengan TB yakni 64.2 tahun, di Taiwan pada pasien berusia $\geq 65$ tahun menemukan rerata usia pasien 75,15 tahun, Penelitian di Bangalore India menemukan proporsi usia terbanyak pada $\geq 40$ tahun yakni $74,47 \%$ dibandingkan usia $<40$ tahun, di Telengana, India mendapatkan proporsi terbanyak pada kelompok usia 55-64 tahun yakni 26,4\%, serta 45-54 tahun sebesar 23,6\%, di India Selatan mendapatkan rerata usia pasien TB-DM yakni 48,6 $\pm 9,3$ tahun, di Bhubaneswar Odisha India rerata usia $51,92 \pm 11,76$ tahun serta penelitian di Luzaka Zambia menemukan proporsi $50,0 \%$ pada usia antara 35-50 tahun. ${ }^{13-19}$ Perbedaan rerata usia yang terjadi pada beberapa penelitian di dunia disebabkan perbedaan populasi dari penelitian.

Penelitian di Jakarta tahun 2013 melapor- 
kan jumlah pasien DMT2 dengan TB paru pada rentang usia 27-80 tahun dengan rerata 58,6 $\pm 10,2$ tahun mempunyai proporsi usia di bawah $<60$ tahun lebih banyak dibandingkan yang berusia $\geq 60$ tahun yakni $79,6 \%$, serta di Padang menemukan $72,41 \%$ pada usia kurang dari 60 tahun dengan rerata usia pasien $54,66 \pm 12,77$ tahun., ${ }^{9} 10$ Beberapa penelitian pasien DM dengan TB menunjukkan proporsi usia yang paling banyak ditemukan yakni rerata di atas 50 tahun. Hal ini menunjukkan bahwa komorbiditas penyakit ini masih banyak ditemukan pada usia yang masih produktif serta terdapat kecenderungan peningkatan insidensi TB pada DM sejalan dengan peningkatan usia seseorang serta risiko terjadinya TB pada pasien DM yang lebih besar pada usia yang lebih tua karena usia tersebut termasuk usia yang berisiko terhadap penyakit. $^{20}$

Berdasarkan jenis kelamin pasien DMT2 dengan TB paru umumnya didominasi oleh lakilaki misalnya di Shandong Cina sebesar 71,4\%, di Taiwan 76,7\%, di Banglaore India 68,08\%, Telengana India 70,83\%, India Selatan 72,0\%, Bhubaneswar Odisha India $75 \% .{ }^{13-18}$ Dua penelitian di Indonesia lainnya juga mendapatkan proporsi yang lebih banyak pada laki-laki dibandingkan perempuan yakni di Jakarta $(55,1 \%)$ dan di Padang $(58,62 \%) .{ }^{9}{ }^{10}$ Penelitian ini mendapatkan hasil yang serupa di Luzaka Zambia yang menemukan perempuan lebih banyak yakni 83,3\%. ${ }^{19}$ Berdasarkan jenis kelamin, maka proporsi laki-laki yang lebih banyak ditemukan hal ini menunjukkan pasien DM laki-laki umumnya dianggap lebih berisiko TB salah satunya disebabkan oleh kebiasaan merokok meskipun proporsi antara jenis kelamin pasien DM dengan TB paru antara laki-laki dan perempuan tidak berbeda secara bermakna. ${ }^{9,10}$

Berdasarkan hasil pengukuran IMT di Shandong Cina menemukan IMT $\geq 18,5 \mathrm{~kg} / \mathrm{m}^{2}$ sebesar $78,6 \%$, di Taiwan rerata IMT $24,37 \mathrm{~kg} / \mathrm{m}^{2}$, di Telengana India mendapatkan rerata IMT yakni $22,7 \mathrm{~kg} / \mathrm{m}^{2} \pm 0,2 \mathrm{~kg} / \mathrm{m}^{2}$ serta di India Selatan de-ngan rerata IMT $20,8 \pm 3,8 \mathrm{~kg} / \mathrm{m}^{2}$, di Luzaka Zambia terbanyak dengan IMT yang normal $(18,5-$ $24,9 \mathrm{~kg} / \mathrm{m}^{2}$ ) yakni $83,3 \% .^{13,14,16,17,19}$ Penelitian di Indonesia lainnya juga menemukan IMT yang juga kebanyakan kategori normal yakni 51,02\% dengan nilai IMT berkisar 14,56 sampai $47,11 \mathrm{~kg} /$ $\mathrm{m}^{2}$ serta nilai tengah $22,5 \pm 5,3 \mathrm{~kg} / \mathrm{m}^{2}$ di Jakarta serta di Padang IMT normal lebih banyak yakni $51,72 \% .{ }^{9}, 10$

Secara umum beberapa penelitian menemukan pasien DMT2 dengan TB mempunyai IMT yang normal yakni, $18,5-24,9 \mathrm{~kg} / \mathrm{m}^{2}$. Pasien DM yang umumnya mempunyai IMT yang lebih biasanya mengalami kecenderungan penurunan berat badan sejalan dengan perjalanan penyakitnya demikian halnya dengan TB paru ditandai dengan penurunan berat badan sehingga kondisi berat badan tersebut memengaruhi kemungkinan IMT pasien DMT2 dengan TB paru ditemukan lebih banyak yang normal. Meskipun demikian faktor gizi mempunyai peranan yang penting dalam memberikan kontribusi terhadap kejadian penyakit termasuk terjadinya TB di Indonesia yang dikaitkan dengan malnutrisi dan DM serta IMT pada pasien menjadi faktor risiko yang terbukti berperan baik di negara maju maupun negara yang berkembang. ${ }^{9,20}$

Rerata lama sakit pada subyek DMT2 dengan TB paru pada penelitian ini berada antara 510 tahun, penelitian di Shandong Cina mendapatkan rerata lama sakit diabetes $\leq 5$ tahun sebesar $42,8 \%, 5-10$ tahun sebesar $35,7 \%$ sedangkan yang sudah lebih dari 10 tahun sebesar 21,4\%. ${ }^{13}$ Ahmed $\mathrm{M}$ et al., di rumah sakit Universitas Ribat Khartoum Sudan menemukan lama diabetes pada pasien DMT2 dengan TB paru sebagian besar 1-10 tahun yakni $78,33 \%$ selanjutnya $11-20$ tahun sebesar 16,67\% dan 21-30 tahun sebesar 5,0\%. ${ }^{21}$ Lin Y et al., pada kegiatan skrining TB pada pasien DMT2, rerata lama diabetes $10,16 \pm 7,37$ tahun. ${ }^{14}$ Penelitian di Jakarta mendapatkan lama terdiagnosis DM berada pada rentang $<1$ tahun sampai 28 tahun dengan rerata 6,7 tahun serta median $5 \pm 5,8$ tahun. Sebagian besar ditemukan pada lama diabetes yang kurang dari 1 tahun yakni $36,73 \%$ serta $30,6 \%$ pada kelompok lama terdiagnosis diabetes sekitar 1-5 tahun. ${ }^{9}$

Lama sakit DM merupakan waktu pertama kali pasien terdiagnosis DM berdasarkan hasil pemeriksaan dokter. Secara umum lama sakit pasien kemungkinan tidak sesuai dengan lama sakit yang sebenarnya. Secara epidemiologis diabetes seringkali tidak terdeteksi dan dikatakan onset atau mulai terjadinya diabetes adalah 7 tahun sebelum diagnosis ditegakkan. ${ }^{1}$ Terjadinya TB pada pasien DM umumnya tidak terkait dengan lamanya se- 
seorang menderita DM, meskipun beberapa penelitian menemukan semakin lama seseorang sakit DM semakin rentang mengalami TB. Penyakit DM dan TB seringkali terdiagnosis secara bersamaan, sehingga beberapa penelitian juga menemukan bahwa lama diabetes tidak ada hubungannya dengan terjadinya TB pada pasien DM khususnya di negara-negara dengan kondisi terjadinya beban ganda kedua penyakit tersebut.

Berbagai bukti yang menunjukkan bahwa kendali glikemik berhubungan dengan menurunnya komplikasi diabetes menyebabkan penyandang diabetes direkomendasikan untuk mencapai dan menjaga gula darah serendah mungkin mendekati normal. ${ }^{1}$ Dalam kriteria pengendalian DM beberapa sasaran yang ingin dicapai yaitu IMT $18,5-23 \mathrm{~kg} / \mathrm{m}^{2}$, tekanan darah sistolik $<140$ $\mathrm{mmHg}$, tekanan darah diastolik $<90 \mathrm{mmHg}$, GDP 80-130 mg/dl, GD2JPP $<180 \mathrm{mg} / \mathrm{dl}, \mathrm{HbA} 1 \mathrm{c}<7 \%{ }^{2}{ }^{2}$ Dalam penelitian ini nilai kadar GDP, GD2JPP, dan $\mathrm{HbA} 1 \mathrm{c}$ pada pasien DMT2 yang mengalami TB paru menunjukkan kadar GDP masih tinggi yakni rerata 202,11 $\pm 78,68 \mathrm{mg} / \mathrm{dl}$, GD2JPP yaitu $283,20 \pm 107,20 \mathrm{mg} / \mathrm{dl}$, dan HbAlc yakni 11,20土 $2,61 \%$. Distribusi proporsi kendali glikemik pada pasien DMT2 dengan dan tanpa TB paru belum mencapai sasaran GDP pada kisaran 80-130 mg/ dl masing-masing $86,7 \%$ dan $80,0 \%$, GD2JPP $<180 \mathrm{mg} / \mathrm{dl}$ 97,8\% dan 95,6\%, HbAlc $<7 \%$ yakni $93,3 \%$ dan $91,1 \%$. Hal ini menunjukkan bahwa kendali glikemik pada pasien masih belum berjalan dengan baik bahkan masih dalam keadaan kendali glikemik yang buruk.

Penelitian oleh Lee PH, et al., di Taiwan yang mengukur kendali glikemik pada subyek dengan DM dengan menggunakan hasil GDP berdasarkan rekomendasi American Diabetes Association (ADA) yakni kendali glikemik yang baik bila $\leq 130 \mathrm{mg} / \mathrm{dl}$ menemukan hanya $28,82 \%$, selebihnya berada pada kendali glikemik yang buruk yakni $71,18 \% .{ }^{22}$

Penelitian oleh Lin $\mathrm{Y}$ et al., pada pasien DMT2 dengan TB yang berusia 65 tahun ke atas menemukan rerata GDP sebesar 147,15 $\pm 58,64$ $\mathrm{mg} / \mathrm{dl}$ sedangkan rerata $\mathrm{HbAlc}$ sebesar 7,57 \pm $1,61 \%$. Sementara itu Boyilla N. \& Madas S, menemukan proporsi $\mathrm{HbA} 1 \mathrm{c}>9 \%$ sebesar $58,33 \%$, HbAlc 7-9\% sebesar 26,39\%, sedangkan HbAlc $<7 \%$ hanya sebesar $15,28 \%$. Kornfeld $\mathrm{H}$ et al., mendapatkan rerata $\mathrm{HbA1c} 10,4 \%$ pada rentang nilai 9,4\%-11,8\%. Ahmed $\mathrm{M}$ et al., menemukan sebagian besar pasien DMT2 dengan TB paru yaitu $58,6 \%$ mempunyai nilai $\mathrm{HbA1c}$ yang tidak terkontrol $(>6,5 \%){ }^{14,16,17,21}$

Penelitian oleh Bokam, BR. \& Thota $\mathrm{P}^{23}$ di India menemukan $93,20 \%$ pasien TB dengan DM mempunyai gula darah yang tidak terkontrol yang ditandai dengan nilai HbA1c $>7 \%$. Penelitian oleh Chiang CY et al. ${ }^{24}$ di tiga rumah sakit di Taiwan menemukan juga keadaan yang sama dengan pasien TB paru dengan DM dengan nilai $\mathrm{HbA} 1 \mathrm{c}<7 \%$ hanya sebesar $11,6 \%$ yang mempunyai $\mathrm{HbA} 1 \mathrm{c} 7-9 \%$ sebesar $21,6 \%$ sedangkan yang HbAlc $>9 \%$ mencapai 39,2\%. Penelitian lainnya oleh Hou X et al., ${ }^{25}$ pada pasien DM yang baru terdiagnosis diabetes di Shandong China menunjukkan hasil dari kelompok dengan HbA1c $\geq 7 \%$ mempunyai rerata tekanan darah sistolik 146,85 \pm $20,22 \mathrm{mmHg}$, rerata tekanan darah diastolik 82,16 $\pm 12,32 \mathrm{mmHg}$, rerata GDP $172,03 \pm 53,30 \mathrm{mg} /$ dl serta rerata GD2JPP $264,33 \pm 80,29 \mathrm{mg} / \mathrm{dl}$ serta rerata $\mathrm{HbA} 1 \mathrm{c} 8,59 \pm 1,71 \%$.

Penelitian oleh Wijayanto $\mathrm{dkk}^{9}$ di salah satu rumah sakit di Jakarta juga menemukan kategori $\mathrm{HbA}$ lc pasien DM dengan TB paru sebagian besar diatas $8 \%$ yakni sebesar $63,3 \%$. Beberapa penelitian ini menunjukkan rerata nilai $\mathrm{HbA1c}$ yang masih cukup tinggi dan kendali glikemik yang belum mencapai sasaran kurang dari 7\%. Hal ini menyebabkan keterkontrolan DM diduga memberi kontribusi terhadap kemungkinan perkembangan TB. Secara umum hasil penelitian ini sejalan dengan banyak penelitian yang menunjukkan bahwa angka kendali glikemik yang belum mencapai sasaran pengendalian DM pada pasien DMT2 dengan TB paru masih tinggi.

Sementara itu rerata GDP, GD2JPP, dan HbA1c pada subyek DMT2 dengan TB paru berdasarkan jenis kelamin, kelompok usia, lama sakit DMT2, pengobatan DMT2, dan IMT menunjukkan nilai yang bervariasi. Berdasarkan jenis kelamin, rerata kadar GDP, GD2JPP, dan HbA1c pada jenis kelamin perempuan lebih tinggi daripada lakilaki yakni 220,96 $\pm 87,08 \mathrm{mg} / \mathrm{dl} ; 293,00 \pm 120,20$ $\mathrm{mg} / \mathrm{dl}$ dan 11,60 $\pm 2,63 \%$. Berdasarkan kelompok usia, subyek yang mempunyai usia kurang atau sama dengan 50 tahun mempunyai rerata kadar GDP, GD2JPP, dan HbA1c yakni masing-masing 
$215,00 \pm 80,24 \mathrm{mg} / \mathrm{dl} ; 297,29 \pm 89,79 \mathrm{mg} / \mathrm{dl}$ dan $11,49 \pm 2,34 \%$ lebih tinggi dibandingkan di atas usia 50 tahun.

Lama sakit DMT2 menunjukkan jangka waktu pertama kali penderita DM didiagnosis menderita diabetes sampai saat penelitian dilakukan yang dalam penelitian ini dikategorikan menjadi 2 kategori yaitu kurang atau sama dengan 5 tahun, dan lebih dari 5 tahun. Hasil penelitian menunjukkan nilai kadar GDP tertinggi ditemukan pada kelompok dengan lama sakit lebih dari 5 tahun. Sedangkan rerata GD2JPP tertinggi ditemukan pada kelompok kurang atau sama dengan 5 tahun sakit DMT2 demikian halnya dengan rerata HbA1c. Lama sakit DMT2 kemungkinan tidak sesuai dengan lama yang sebenarnya karena umumnya pasien tidak menyadari diri telah mengalami sakit DMT2 sebelum ke pelayanan kesehatan.

Penelitian oleh Bokam, BR. \& Thota P di India berdasarkan lamanya diabetes ditemukan lama diabetes $<5$ tahun mempunyai rerata $\mathrm{HbAlc}$ $9,16 \%$, lama diabetes 5-10 tahun sebesar 8,49\% sedangkan yang lama diabetes lebih dari 10 tahun mempunyai rerata $\mathrm{HbA} 1 \mathrm{c} 9,0 \%$. Hasil penelitian ini menunjukkan bahwa kontrol glikemik pada pasien TB-DM tidak berjalan sesuai dengan harapan yakni nilai $\mathrm{HbAlc}<7 \% .^{23}$

Jenis pengobatan DM menunjukkan upaya medis yang dilakukan oleh dokter untuk mengontrol kadar gula darah pasien. Berdasarkan pengobatan diabetes yang terdiri dari tiga kelompok yakni pasien yang menggunakan obat hipoglikemik oral $(\mathrm{OHO})$, insulin, serta kombinasi $\mathrm{OHO}$ dan insulin menunjukkan perbedaaan rerata antara kadar GDP, GD2JPP dan HbA1c. Pada kelompok dengan pengobatan kombinasi $\mathrm{OHO}$ dan insulin memiliki kadar GDP dan GD2JPP yang tertinggi yakni masing-masing $230,50 \mathrm{mg} / \mathrm{dl}$ dan 297,67 $\mathrm{mg} / \mathrm{dl}$. Sedangkan rerata nilai HbAlc tertinggi didapatkan pada kelompok dengan pengobatan menggunakan insulin yakni, 12,23\%. Salah satu faktor yang paling penting dari pengobatan DM adalah keterkontrolan DM yang tercermin dari nilai kadar HbA1c. Pengobatan DMT2 pada pasien secara umum mempunyai proporsi penggunaan obat non insulin yang masih tinggi, hal ini salah satunya disebabkan oleh sebagian pasien menolak disebabkan penggunaan insulin yang dianggap tidak praktis oleh pasien. Demikian hal- nya penelitian di salah satu rumah sakit di Jakarta menemukan penggunaan obat non insulin seki$\operatorname{tar} 69,4 \%$ termasuk penderita DMT2 dengan TB Paru. ${ }^{9}$ Hal ini menunjukkan jenis pengobatan diabetes tidak memberikan pengaruh terhadap status metabolik pada pasien DMT2 dengan TB paru.

Perubahan berat badan pada penyandang diabetes melitus salah satunya diketahui dari parameter IMT. Berdasarkan IMT yang dikelompokkan IMT kurang $<18,5 \mathrm{~kg} / \mathrm{m}^{2}$, IMT normal $18,5-$ $22,99 \mathrm{~kg} / \mathrm{m}^{2}$ dan IMT lebih $>23 \mathrm{~kg} / \mathrm{m}^{2}$ nampaknya terdapat perbedaan variasi kadar GDP, GD2JPP, dan $\mathrm{HbA} 1 \mathrm{c}$. Pada IMT yang kurang terdapat nilai GDP yang paling tinggi yakni $218,83 \mathrm{mg} / \mathrm{dl}$. Nilai rata-rata GD2JPP tertinggi berada pada IMT $>23$ $\mathrm{kg} / \mathrm{m}^{2}$, yakni $288,56 \mathrm{mg} / \mathrm{dl}$ demikian juga rerata nilai $\mathrm{HbA}$ 1c yakni $11,33 \%$.

Penelitian di Taiwan pada subyek dengan kendali glikemik yang buruk didapatkan proporsi yang tertinggi pada perempuan $(58,7 \%)$, IMT $25,0-30,0 \mathrm{~kg} / \mathrm{m}^{2}(44,8 \%)$, dan usia rerata pada 58,8 tahun. Sedangkan pada subyek DM dengan TB ditemukan $85,71 \%$ yang mempunyai kendali glikemik yang buruk yang terdistribusi $46,03 \%$ pada kelompok usia $<65$ tahun, laki-laki $47,62 \%$, IMT $<25 \mathrm{~kg} / \mathrm{m}^{2}$ sebesar $55,56 \%{ }^{22}$

Hasil berbeda pada penelitian di India melaporkan rerata $\mathrm{HbAlc}$ yang diperoleh berdasarkan jenis kelamin rata-rata $\mathrm{HbA1c}$ pada laki-laki ditemukan 9,5\% lebih tinggi dibandingkan perempuan yakni hanya $8,5 \%$. Berdasarkan kelompok usia 40-60 tahun ditemukan 9,02\%, usia di atas 60 tahun mempunyai $\mathrm{HbA1c} 8,97 \%$. Kategori lainnya menurut IMT didapatkan nilai HbA1c pada IMT normal $(8,79 \%)$ lebih rendah dibandingkan dengan IMT kurang $(11,7 \%)$ dan IMT lebih $(9,25 \%) .{ }^{23}$ Penelitian di Taiwan berdasarkan rentang usia 35-64 tahun didapatkan nilai HbAlc $>9 \%$ sebanyak lebih dari $20 \%$ dengan proporsi tertinggi pada kelompok usia 55-64 tahun. Penelitian lainnya di Shandong China menunjukkan hasil dari kelompok dengan $\mathrm{HbA1c} \geq 7 \%$ lebih banyak perempuan $(59,4 \%)$, rerata usia $60,39 \pm 8,99$ tahun, rerata IMT $27,44 \pm 3,27 \mathrm{~kg} / \mathrm{m}^{2} .{ }^{24,25}$

Kendali glikemik pada pasien DMT2 menunjukkan nilai yang belum mencapai sasaran pengendalian DM terutama pada kelompok DMT2 dengan TB paru. Hal ini menunjukkan perlu upaya pemantauan yang lebih efektif sehingga pe- 
ngendalian dan pengobatan penyakit dapat berjalan secara baik terutama pada kondisi komorbiditas dengan TB paru.

\section{KESIMPULAN DAN SARAN}

Penelitian ini mendapatkan rerata GDP, GD2JPP, dan HbA1c pada pasien DMT2 dengan TB paru lebih tinggi dibandingkan DMT2 tanpa TB paru dan berbeda secara bermakna berdasarkan pemeriksaan glukosa darah GD2JPP dan HbA1c. Hal ini menunjukkan kriteria pengendalian DM yang belum mencapai sasaran. Perlu dilakukan upaya pemantauan kendali glikemik diabetes melitus yang lebih efektif sehingga pengelolaan DM dapat berjalan secara baik dan efektif terutama pada kondisi komorbiditas DMT2 dengan TB paru.

\section{UCAPAN TERIMA KASIH}

Kepada Direktorat Jenderal Penguatan Riset dan Pengembangan Kementerian Riset, Teknologi dan Pendidikan Tinggi atas Hibah Penelitian Disertasi Doktor (PDD) tahun 2018 serta Direktur RSUD Dr. Soetomo dan RSUD Dr. Mohamad Soewandhie Surabaya atas izin lokasi penelitian.

\section{DAFTAR PUSTAKA}

1. Soegondo S., Pradana S., \& Subekti I. (eds). Penatalaksanaan Diabetes Melitus Terpadu. Jakarta: Badan Penerbit FKUI; 2013.

2. Perkumpulan Endrokrinologi Indonesia. Konsensus Pengelolaan dan Pencegahan Diabetes Melitus Tipe 2 di Indonesia. Jakarta: PB. PERKENI; 2015.

3. IDF. Diabetes Atlas Sixth Edition, International Diabetes Federation. Brussels: http:/www. eatlas.idf.org; 2013.

4. Kementerian Kesehatan. Laporan Nasional Riset Kesehatan Dasar. Jakarta: Kementerian Kesehatan RI; 2013.

5. WHO. Global Tuberculosis Report 2015. WHO; 2015.

6. Esmail H, Barry C.E., Young D.B., \& Wilkinson R.J, The Ongoing Challenge of Latent Tuberculosis. Phil.Trans.R.Soc. 2014;(369): 1-14.

7. Kapur A, Harries A.D., Lonnroth K, Bygjerg C \& Lefebvre P, Diabetes and Tuberculosis Old Associates Posing a Renewal Public
Health Challenge. European Endrocinology; 2009;12-14.

8. Kapur A \& Harries A.D. The Double Burden of Diabetes and Tuberculosis - Public Health Implications. Diabetes Research and Clinical Practice. 2013;(101):10-19.

9. Wijayanto A, Burhan E., Nawas A., \& Rochsismandoko, Faktor Terjadinya Tuberkulosis Paru pada Pasien Diabetes Melitus Tipe 2. J. Respir Indo. 2015;(35):1-11.

10. Fauziah DF, Basyar M \& Manaf A. Insidensi Tuberkulosis Paru pada pasien Diabetes Melitus Tipe 2 di Ruang Rawat Inap Penyakit Dalam RSUP Dr. M. Djamil Padang. Jurnal Kesehatan Andalas. 2016;5(2):349-54.

11. Elorriaga G.G., \& Pineda D.R., Type 2 Diabetes Mellitus as a Risk Factor for Tuberculosis. Mycobacterial Diseases Journal. 2014;(4): 1-6.

12. Cahyadi A., \& Venty. Tuberkulosis Paru pada Pasien Diabetes Mellitus. J Indon Med Assoc. 2011;(61):174-78.

13. Zhao W, Shi L, Fonseca V.A, He J, Shao D, Zhao J, Chen Q \& Yin A. Screening Patients with Type 2 Diabetes for Active Tuberculosis in Communities of China. Diabetes Care Journal. 2013;(36):159-160.

14. Lin Y.H.,, Chen C.P., Chen P.Y., Huang J.C., Ho C, Weng H.H., Tsai Y.H., \& Peng Y.S., Screening for Pulmonary Tuberculosis in Type 2 Diabetes Elderly : a Cross-Sectional Study in a Community Hospital. BMC Public Health. 2015;(15):1-8.

15. Prakash B.C., Ravish K.S., Prabhakar B, Ranganath T.S., Naik B, Satyanarayana S, Isaakidis P. \& Kumar A.M.V., Tuberculosis Diabetes Mellitus Bidirectional Screening at a Tertiary Care Centre, South India. Public Health Action. 2013;(3):18-21.

16. Boyilla N., \& Madas S,. Relationship between Diabetes Mellitus and Pulmonary Tuberculosis and Outcome of Treatment. International Journal of Advances in Medicine. 2016;(3):504-08.

17. Kornfeld H, West K, Kane K, Kumpatla S, Zacharias R.R., Martinez-Bolzano C, Li W., \& Viswanathan V. High Prevalence and Heterogeneity of Diabetes in Patients with TB in South India. Journal.publication.chesnet.org. 
2016;1501-08.

18. Das S, Das E,Bhuyan K, Prusty B, Barik M, Yadav VS \& Hussain T., Biderectional Screening of Tuberculosis Patients for Type 2 Diabetes and Diabetes Patients for Tuberculosis in Bhubaneswar, Odisha. International Journal of Community Medicine and Public Health. 2017;4(7):2435-42.

19. Fwoloshi S, Hachaambwa L.M., Chiyenu K.O., Chirwa L, Hoffman T.W., Ngalamika O \& Bailey S.L,. Screening for Diabetes Mellitus among Tuberculosis Patients: Finding from a Study at a Tertiary Hospital in Lusaka, Zambia. Canadian Journal of Infectious Disease and Medical Microbiology. 2018;1-5.

20. Wulandari D.R., \& Yani J.G., Diabetes Melitus dan Permasalahannya pada Infeksi Tuberkulosis. .J Respir Indo. 2013;(33):126-34.

21. Ahmed M, Omer I, Osman S.M., \& Ahmed-Abakur E.H., Association between Pulmonary Tuberculosis and Type 2 Diabetes in Sudanese Patients. The International Journal of Microbiology. 2017; (6): 97-101.

22. Bokam B.R., \& Thota P,. Effect of Glycemic
Control of Pulmonary Tuberculosis in Diabetics. India Journal of Basic and Applied Medical research. 2016;(5):198-207.

23. Chiang C.Y., Bai K.J., Lin H.H., Chien S.T., Lee J.J., Enarson D.A., Lee T.I., \& Yu M.C. The Influence of Diabetes, Glycemic Control, and Diabetes-Related Comorbidities on Pulmonary Tuberculosis. Journal.pone.2015; 1-15.

24. Lee P.H., Fu H, Lai T.C., Chiang C.Y., Chan C.C., \& Lin H.H., Glycemic Control and the Risk of Tuberculosis : A Cohort Study. Journal PLOS Medicine. 2016;1-15.

25. Hou X.H., Wang C, Wang S, Yang W, Ma Z, Wang Y, Li C, Li M, Zhang X, Zhao X, Sun Y, Song J, Lin P, Liang K, Gong L, Wang M, Liu F, Li W, Yan F, Yang J, Wang L, Tian M, Liu J, Zhao R, Chen S \& Chen L. Fluctuation between Fasting and 2-H Postload Glucose State is Associated with Glomerular Hyperfiltration in Newly Diagnosed DiabetesPatients with HbA1c $<7 \%$. Journal PLOS ONE. 2014; (9):1-7. 